\section{References}

1 Arnarson BGW. Inflammatory polyradiculopathies. In: Dyck PJ, Thomas PK, Lambert EHW, eds. Peripheral neuropathy. Philadelphia : WB Saunders, 1975:1110-48.

2 Dowling PC, Cook SD. Role of infection in Guillain-Barré syndrome: laboratory confirmation of herpesviruses in 41 cases. Ann Neurol $1981 ; 9$ (suppl):44-55.

${ }^{3}$ Rhodes KM, Tattersfield AE. Guillain-Barré syndrome associated with campylobacter infection. $\mathrm{Br}$ Med $\mathcal{f} 1982 ; 285: 173-4$.

4 Constant OC, Bentley CC, Denman AM, Lehane JR, Larson HE. The Guillain-Barré syndrome following campylobacter enteritis with recovery after plasmapheresis. Fournal of Infection 1983;6:89-91.

5 Speed BR, Kaldor J, Cavanagh P. Guillain-Barré syndrome associated with Campylobacter jejuni enteritis. Fournal of Infection 1984;8:85-6.

- Butzler JP, Dekeyser P, Detrain M, Dehaen F. Related vibrio in stools. f Pediatr 1973;82:493-5.

'Skirrow MB. Campylobacter enteritis: a "new" disease. Br Medf 1977;ii: 9-11.

${ }^{8}$ Asbury AK. Diagnostic considerations in Guillain-Barré syndrome. Ann Neurol 1981;9 (suppl):1-5.

- Kaldor J, Pritchard H, Serpell A, Metcalf W. Serum antibodies in campylobacter enteritis. $\mathcal{f}$ Clin Microbiol 1983;18:1-4.

10 Pesce MA, Strande CS. A new micromethod for determination of protein in cerebrospinal fluid and urine. Clin Chem 1973;19:1265-7.

11 Overby LR, Miller JP, Smith ID, Decker RH, Ling CM. Radioimmunoassay of hepatitis B virus associated (Australia) antigen employing $I^{125}$ antibody. Vox Sang 1973;suppl 24:102-13.

12 Hayes $\mathrm{K}$, Gibas $\mathrm{H}$. Placental cytomegalovirus infection without fetal involvement following primary infection during pregnancy. $\mathcal{f}$ Pediatr $1971 ; 79: 401-5$.
${ }^{13}$ Blaser MJ, Reller LB. Campylobacter enteritis. N Engl f Med 1981 ;305: 1444-52.

14 Dart GC, Kaldor J. Immunoglobulins in the cerebrospinal fluid of patients with Guillain-Barré syndrome. Med J Aust 1981;ii:405-7.

15 Knowles M, Saunders M, Currie S, Walton JN, Field EJ. Lymphocyte transformation in the Guillain-Barré syndrome. Lancet $1969 ; \mathrm{ii}: 1168-70$.

16 Iqbal A, Oger JJ-F, Arnason BGW. Cell-mediated immunity in idiopathic polyneuritis. Ann Neurol $1981 ; 9$ (suppl):65-9.

17 Cook SD, Dowling PC. The role of autoantibody and immune complexes in the pathogenesis of Guillain-Barré syndrome. Ann Neurol $1981 ; 9$ (suppl):70-9.

18 Latov N, Gross RB, Kastelman J, et al. Complement-fixing antiperipheral nerve myelin antibodies in patients with inflammatory polyneuritis and with polyneuropathy and paraproteinemia. Neurology $(N Y)$ $1981 ; 31: 1530-4$.

19 Vedeler CA, Nyland H, Matre R. Antibodies to peripheral nerve tissue in sera from patients with acute Guillain-Barré syndrome demonstrated by a mixed haemagglutination technique. Fournal of Neuroimmunology $1982 ; 2: 209-14$.

20 Finne J, Leinonen M, Makela PH. Antigenic similarities between brain components and bacteria causing meningitis. Lancet 1983;ii:355-7.

21 Ruiz-Palacios GM, Torres J, Torres I, Escamilla E, Ruiz-Palacios BR, Tamayo J. Cholera-like enterotoxin produced by Campylobacter jejuni. Lancet 1983;ii:250-3.

22 Van Heyningen WE. Gangliosides as membrane receptors for tetanus toxin, cholera toxin and serotonin. Nature 1974;249:415-7.

(Accepted 9 April 1984)

\title{
Circumstances of death from asthma
}

\author{
A J JOHNSON, A J NUNN, A R SOMNER, D E STABLEFORTH, C J STEWART
}

\begin{abstract}
Mortality from asthma in England and Wales has remained unchanged for at least 20 years, even in the age group 15-44. Yet in those 20 years "modern" drugs have been introduced for the treatment of asthma, such as $\beta_{2}$ agonist bronchodilators and corticosteroids. Why do patients still die?

Detailed review of the circumstances of 90 deaths from asthma showed that a few were inevitable but that in the remainder four main sets of circumstances in the fatal attack contributed to the death. These were, firstly, the patient's failure to recognise the severity of the asthma;
\end{abstract}

Kent and Canterbury Hospital, Canterbury CT1 3NG

A J JOHNSON, MB, MRCP, consultant chest physician

MRC Tuberculosis and Chest Diseases Unit, Brompton Hospital, London SW3 6HP

A J NUNN, MSC, statistician

Preston Hospital, North Shields, Tyne and Wear NE29 0LR

A R SOMNER, MD, FRCP, consultant chest physician

East Birmingham Hospital, Birmingham B9 5ST

D E STABLEFORTH, MB, MRCP, consultant in thoracic medicine

Ipswich Hospitals, Suffolk

C J STEWART, MD, lately consultant chest physician

Correspondence to: Dr C J Stewart, 159 Henley Road, Ipswich, Suffolk IP1 4NU. secondly, very rapid progress in the severity of the attack; thirdly, misjudgment in the management of the attack; and, fourthly, delay from many causes.

Patients admitted to hospital with severe acute asthma usually survive. Those at risk of a life threatening attack should be identified and taught to monitor the severity and progress of their asthma objectively. Their direct admission to hospital should be facilitated.

\section{Introduction}

In 1982 the Research Committee of the British Thoracic Association (Society) reported on the death from asthma of 90 patients aged 15-64 years living in the West Midlands and Mersey regions in $1979 .{ }^{1}$ Like other reports of death from asthma in recent years, ${ }^{2-5}$ that report considered principally the deficiencies of management and the modern drug treatment preceding the fatal attack. In this paper we review in more detail than was possible in the original report the circumstances of the fatal attack of asthma.

\section{Methods}

The procedure and methods were fully described in the original report. ${ }^{1}$ Of particular value in that retrospective inquiry was the independent panel of three physicians who reviewed and assessed each case. Altogether 153 patients died, of whom they agreed that 90 had died of asthma. They then assessed the management and treatment of the asthma in the last year and the last month of life and the events of the fatal attack. Our report is largely based on those assessments (see tables I and II). The 12 case histories set out below represent the main categories of death. 
TABLE I-Summary of important factors contributing to death from asthma of 90 patients

\begin{tabular}{|c|c|c|}
\hline & $\begin{array}{c}\text { No of } \\
\text { patients }\end{array}$ & $\begin{array}{l}\% \text { of } \\
\text { patients }\end{array}$ \\
\hline $\begin{array}{l}\text { (1) Asthma not diagnosed: } \\
\text { (a) In life } \\
\text { (b) In fatal attack }\end{array}$ & $\left.\begin{array}{l}4 \\
5\end{array}\right\}$ & 10 \\
\hline $\begin{array}{l}\text { (2) Some aspects of management or supervision deficient: } \\
\text { (a) General practitioner } \\
\text { (b) Hospital }\end{array}$ & 25 of 26 & \\
\hline $\begin{array}{l}\text { (3) Asthma not controlled by routine treatment. Should } \\
\text { have been given: } \\
\text { (a) Bronchodilator or increased dose } \\
\text { (b) Oral corticosteroids or increased dose } \\
\text { (c) Trial of inhaled corticosteroids } \\
\text { (d) Trial of sodium cromoglycate }\end{array}$ & $\begin{array}{l}24 \\
44 \\
45 \\
59\end{array}$ & \\
\hline $\begin{array}{l}\text { (4) Patient not fully compliant with management or drug } \\
\text { treatment }\end{array}$ & 48 & 53 \\
\hline $\begin{array}{l}\text { (5) Severity of fatal attack not appreciated by: } \\
\text { (a) Patient } \\
\text { (b) General practitioner } \\
\text { (c) Hospital doctor }\end{array}$ & $\begin{array}{r}67 \text { of } 87 \\
25 \text { of } 36 \\
3 \text { of } 13\end{array}$ & $\begin{array}{l}77 \\
69 \\
23\end{array}$ \\
\hline (6) Death probably inevitable & 13 & 14 \\
\hline (7) Severe, rapidly progressing fatal attack & 23 & 26 \\
\hline (8) Change of general practitioner in last six months of life & 12 & 13 \\
\hline $\begin{array}{l}\text { (9) Attendance of locum or deputising general practitioner } \\
\text { in fatal attack }\end{array}$ & 13 of 41 & 32 \\
\hline (10) Delays involving ambulance service & 12 of 34 & 35 \\
\hline
\end{tabular}

TABLE II-Circumstances of final phase of fatal attack (90 patients)

\begin{tabular}{|c|c|c|c|}
\hline & $\begin{array}{c}\text { No of } \\
\text { patients }\end{array}$ & & $\begin{array}{c}\text { No of } \\
\text { patients }\end{array}$ \\
\hline \multirow{6}{*}{$\begin{array}{l}\text { Saw general practitioner and } \\
\text { treated at home } \\
\text { Saw general practitioner and } \\
\text { sent to hospital } \\
\text { Called general practitioner; } \\
\text { patient dead or moribund } \\
\text { Saw prison medical officer } \\
\text { Already in hospital }\end{array}$} & 7 & \multirow{6}{*}{$\begin{array}{l}\text { Emergency } 999 \text { call } \\
\text { Taken to casualty department } \\
\text { Found dead } \\
\text { Emergency } 999 \text { call because } \\
\text { general practitioner delayed } \\
\text { Taken to hospital because } \\
\text { general practitioner delayed }\end{array}$} & 30 \\
\hline & 8 & & $\begin{array}{r}2 \\
13\end{array}$ \\
\hline & & & \\
\hline & 21 & & 4 \\
\hline & $\begin{array}{l}1 \\
3\end{array}$ & & 1 \\
\hline & 40 & & 50 \\
\hline
\end{tabular}

\section{Circumstances of death}

\section{DEATH INEVITABLE OR DOUBTFULLY PREVENTABLE}

In 10 of the 90 patients death was thought to have been inevitable; in a further three the panel disagreed, and these cases have been classed as doubtfully preventable. Five of these 13 patients lived alone and were found dead, another five died within 30 minutes of the onset of the fatal attack, and one was allowed to die. The remaining two died in hospital, one as a result of bilateral pneumothoraces after intermittent positive pressure respiration and the other from cardiac arrest on the second day of receiving ventilation.

Case 6-A woman aged 53 was allowed to die. She had had asthma from the age of 13 of varied frequency, severity, and duration of attacks. In 1968 she was ventilated for four days for severe asthma. Afterwards she suffered continuous wheeziness and increasing breathlessness on exertion. In the last year of life she did not leave her home and was several times bedridden for a few days. She repeatedly refused admission to hospital because of her experience of ventilation.

Case 153-This patient, a widow aged 63, was typical of those who lived alone and were found dead. She was reported to have had her first attack of asthma at the age of 26 , four years after the start of an unhappy marriage. Attacks were almost invariably associated with domestic strife. Between 1966 and 1968 she had eight hospital admissions for severe acute attacks. Her husband died in 1971, after which she continued to have frequent but relatively mild attacks, invariably controlled with a bronchodilator inhaler. She was well when her sister left her at $11 \mathrm{pm}$ on the night that she died but was found next morning lying beside her bed. There was no telephone in the house.

\section{RAPIDLY PROGRESSING SEVERE ATTACKS}

The fatal attack of asthma was known to have lasted for less than an hour in 23 of the 77 patients who were not admitted to hospital alive or who were in hospital when the attack occurred.

Case 31-An unmarried male opera singer aged 40 had had a dry, intermittent cough for five weeks, diagnosed as mild bronchitis. He was given only a bronchodilator inhaler, but he never used this for fear of affecting his voice. He had two attacks of coughing and retching lasting half an hour, one after hill walking and the other after a heavy lunch. The day he died he had returned home fit and well. Shortly after retiring at $11 \mathrm{pm}$ he called his brothers to fetch a doctor. He was on his hands and knees fighting for breath. There was delay in contacting the doctor because the public telephone had been vandalised. Once contacted the general practitioner attended promptly, only to find the patient dead.

Case 96-This patient, aged 17, was said to have been wheezing from the age of 3. His first recognised attack of asthma occurred at the age of 9 when he was recovering from measles. On average he saw or called his general practitioner four or five times a year for attacks of asthma. Between 1974 and 1976 he had four hospital admissions for severe acute attacks; afterwards he relied solely on a bronchodilator inhaler. Since leaving school at 16 he had been well and free of asthma. The evening that he died he started laughing while watching television, and this, as on previous occasions, made him breathless. He retired to his bedroom and was found by his father in great distress. The general practitioner was called from his evening surgery and attended within 10 minutes but was unable to resuscitate him. The nearest hospital was 18 miles $(28 \mathrm{~km})$ away.

Remarks-The great speed with which asthma attacks may proceed is such that if there is delay of any kind or even if there is a prearranged "self admission" scheme there is small chance of the patient surviving.

\section{SEVERITY OF ATTACK NOT APPRECIATED BY PATIENT OR RELATIVE}

The panel considered that $67(77 \%)$ of 87 patients at home delayed calling for medical help probably because they did not appreciate the severity of the asthma attack.

Case 18-A widow aged 53 had suffered from periodic attacks of asthma from the age of 7 until the birth of her first child at the age of 27. This was followed by 21 years of remission until the age of 48, after which she had continuous asthma and breathlessness on exertion and fairly frequent exacerbations but managed her housework, gardening, and shopping. Her routine treatment was salbutamol $4 \mathrm{mg}$ four times a day, prednisone $5 \mathrm{mg}$ four times a day, cromoglycate inhalations four times a day, and promethazine $25 \mathrm{mg}$ at night; for exacerbations she was given methylprednisolone $40 \mathrm{mg}$ intramuscularly. On the day of her death she was breathless on getting up and spent two hours between the bedroom, bathroom, and lavatory, coughing, retching, and gasping for breath. Her daughter, aged 16, paid little attention, as these attacks had occurred before, and continued her studies until she heard a thud. The general practitioner arrived within 15 minutes and found the mother dead.

Remarks-Inherent in the asthmatic state is that some patients have reduced perception of the degree of breathlessness. ${ }^{6}$ This failure to perceive the severity of the asthma can be understood in a lifelong sufferer who does not know what it is like not to be breathless, yet it is also present in those whose asthma starts later in life and in those who suffer only sporadic attacks. ${ }^{6} 7$ There are also those who have suffered and survived severe acute attacks who do not summon medical aid as they do not consider the possibility of a fatal outcome.

\section{SEVERITY OF ASTHMA NOT APPRECIATED BY ATTENDING DOCTOR}

The panel considered that the attending doctor had failed to appreciate the severity of the asthma in the fatal attack in 25 out of 36 patients at home and in three out of 13 in hospital.

Case 10-A man aged 36 had begun to have asthma at the age of 9 . He had lost a lot of time at school and work. His wife often found him on hands and knees fighting for breath. Six weeks before death he had a severe attack for which he was given an increased dose of oral corticosteroids, but with very little improvement. Seven days before death a locum general practitioner withdrew his corticosteroids, after which he was much worse and had difficulty gasping out single words. The deputising services were called at $730 \mathrm{am}$. At 1040 the doctor who attended made few comments and gave a prescription which could not be dispensed until $5 \mathrm{pm}$, as it was Sunday. On returning from the chemist the wife found the patient lying on the garden path in extremis. He was dead when another deputising doctor arrived at $630 \mathrm{pm}$.

Case 120-A woman aged 44 had had asthma since the age of 39 . From the start it did not respond to simple measures, so she was given oral corticosteroids. She continued to have frequent, moderately severe exacerbations, treated by increasing the dose of corticosteroid drugs. Two weeks before death she was admitted to hospital to stabilise her asthma. After two weeks in hospital the notes read "cold, clammy, chest full of spasm and few moist sounds." At night the nurse reported that she was "restless and wheezy"; at $830 \mathrm{am}$ an aminophylline suppository was ordered by phone. There was no response and the patient was reported dead at $9 \mathrm{am}$.

Remarks-The so called "silent chest" of severe life threatening asthma may be most deceptive to those who have not encountered it before and who do not observe the signs such as increased pulse and 
respiration rates of severe asthma. In the final phase of the fatal attack wheezy respiration was noted by the doctor or relatives in only six of 67 of the patients. They described the patients as "gasping," "gulping," "retching," and so on, suggesting a much reduced ventilation.

\section{CHANGE OF DOCTOR}

For various reasons $12(13 \%)$ of the patients had a change of doctor in the last six months of life. Of the 41 patients who called a doctor in the fatal attack, $13(32 \%)$ were attended by the deputising services or locums unfamiliar with the patient. One patient was sent to hospital and another refused to be admitted.

Case 39-A man aged 63 had had his first attack of asthma at the age of 51 , when he was admitted to hospital. He had four further admissions over the next two years. Between these attacks and subsequently he continued at work. The night that he died he returned from work at $8 \mathrm{pm}$ and prepared to go to his club. He rapidly became breathless. His wife called the deputising services. No doctor having attended by $930 \mathrm{pm}$, the deputising services were again contacted, when the wife was told "what more could she expect as the patient was number four on the doctor's call list." The doctor arrived 20 minutes later to find the patient dead (see also case 10, above).

Case 79-A woman aged 33 had had sporadic attacks of asthma since the age of 7. Throughout her illness she had consulted homoeopathists, herbalists, and hypnotists, chiefly to avoid taking corticosteroid drugs which her general practitioner gave her for acute attacks. At the start of the fatal attack her general practitioner gave her an antibiotic, oral orciprenaline, and corticosteroids. The mother reported that she threw the tablets away and consulted a herbalist, who called on her twice during the fatal attack.

Remarks-After a change of address it may take more than three weeks to transfer the medical records. In these circumstances and in an emergency, when the patient is confronted by a strange doctor, the records are not available. Patients-particularly women-will occasionally change their doctors and go to other extremes in the hope that they will not have to take oral corticosteroid drugs.

\section{AMBULANCE SERVICE}

Case 132-A woman aged 58 with longstanding severe chronic asthma lived in a small town. The fatal attack occurred while she was visiting friends to play bridge. The ambulance arrived 40 minutes after the call, as it had had to wait while the police dragged an attempted suicide from a river. The patient lived for 20 hours on a ventilator.

Case 101-A 21 year old woman had had unstable acute asthma since the age of 3 . She was recently married and went to live on a new housing estate, where they had not registered with a local doctor. The nearest ambulance was 10 miles $(16 \mathrm{~km}$ ) away, the crew did not know the layout of the new housing estate, and it took nearly an hour to arrive. She was dead on arrival at the nearest equipped hospital, nine miles away.

Case 163-This patient, a woman aged 49, suffered her first attack of asthma six months before death. A month later she had a more persistent attack and saw her general practitioner for the first time. She improved after oral corticosteroids and returned to work after three weeks. Two months later she had her third attack of asthma, for which she was given $10 \mathrm{mg}$ prednisolone twice daily. Two days later she was worse and was unable to contact her doctor. An emergency 999 call was made and an ambulance arrived within a few minutes but did not take her to hospital. The general practitioner was contacted and arrived an hour later, by which time the patient was moribund. The nearest fully equipped hospital was less than 10 minutes from her home.

Remarks-The ambulance called by the 999 service attended within 15 minutes in 28 of 34 calls. In five other instances delay was caused by an instruction to ambulance personnel not to take patients to hospital without the general practitioner being consulted or, if he was not available, a deputising doctor first being called. On two further occasions the ambulance officers, seeing the great distress of the patients, took the patient to hospital without complying with this instruction.

\section{Comment}

Severe life threatening attacks of asthma almost invariably respond to medical treatment. The reason that these patients died was that the circumstances of the fatal attack frequently resulted in insufficient time for medical aid to be summoned, or if summoned there were delays that made death inevitable. The principal causes were, firstly, failure of the patient, relative, or medical attendant to appreciate the severity of the attack; secondly, the rapid progression of the attack; and, finally, many different causes of delay in contacting the medical services, attendance of medical aid, and the transport of patients to hospital.

Out of 87 patients who were not in hospital at the time of the fatal attack, $67(77 \%)$ failed to appreciate the severity of the fatal attack and delayed calling for medical help. Many patients with asthma, particularly lifelong sufferers, do not appreciate the severity of their breathlessness. ${ }^{6} 7$ They must be taught to monitor objectively the progress of the attack and its response to treatment. Serial measurements of the peak flow rate are probably the simplest and most convenient test. This should be part of the instruction of all patients previously admitted to hospital with severe acute asthma attacks, all patients known to have had rapidly progressing severe attacks, and patients who have never been in hospital for asthma but are known to have unstable asthma or have been treated for severe acute attacks at home.

There is no certain way of recognising the patient who is likely to have a rapidly progressing severe asthma attack unless he has suffered previously. Many of the fatal attacks at home occurred at night or weekends-when it is not always easy to get prompt attention from the general practitioner services. Even if the attack occurs in normal working hours it is not always possible for the general practitioner to attend promptly. It is therefore better for the patient to go without delay to the nearest appropriate hospital, and the hospital should preferably arrange a self admission service for these patients. ${ }^{8}$ Such hospitals are geared to receive and treat the patient, and arrangements are made for the ambulance service to be alerted and prompt admission arranged. In some circumstances it may be quicker for the patient to be taken to hospital by relatives or friends in a car, and it may be necessary to instruct a relative to give intramuscular corticosteroids, a bronchodilator aerosol, and oxygen.

A reduction of deaths from asthma will be achieved only when patients are taught to recognise the severity of the asthma and obtain prompt admission to hospital.

This report is based on information collected in the course of the British Thoracic Association (Society) Research Committee's confidential inquiry into death from asthma in two regions of England. C J Stewart, the coordinator of the study, was in receipt of a personal grant from the Medical Research Council.

We gratefully acknowledge the help given by members of the asthma death subcommittee. Chairmen were Dr E A Hills (to April 1980) and Dr A R Somner (from April 1980). Members were: Dr A M Adelstein (lately of the Office of Population Censuses and Surveys), Sir Cyril Clarke (Medical Services Study Group of the Royal College of Physicians), Professor T J H Clark, Dr M S Dunnill, Dr A J Johnson, Mr A J Nunn, Dr D E Stableforth, Professor A G W Whitfield (Medical Services Study Group of the Royal College of Physicians), and Dr C J Stewart.

\section{References}

${ }^{1}$ British Thoracic Association. Death from asthma in two regions of England. Br Med f 1982;285:1251-5.

2 Cochrane GM, Clark TJH. A survey of asthma mortality in patients between ages of 35 and 64 in the Greater London hospitals in 1971. Thorax 1975;30:300-5.

3 Macdonald JB, Seaton A, Williams DA. Asthma deaths in Cardiff in 1963-74: 90 deaths outside hospital. Br Med F 1976;i:1493-5.

4 Macdonald JB, Macdonald ET, Seaton A, Williams D. Asthma deaths in Cardiff 1963-74: 53 deaths in hospital. Br Med F 1976;ii:721-3.

5 Ormerod LP, Stableforth DE. Asthma mortality in Birmingham 1975-7: 53 deaths. $\mathrm{Br}$ Med $\mathcal{f}$ 1980;280:687-90.

- Burdow JGW, Juniper EF, Killian KJ, Hargreave FE, Campbell EJM. The perception of breathlessness in asthma. Am Rev Respir Dis 1982; $126: 825-8$.

${ }^{7}$ Rubinfeld AR, Pain MCF. Perception of asthma. Lancet 1976;i:882-7.

${ }^{8}$ Crompton GK, Grant IWB. Edinburgh emergency asthma admission service. $\mathrm{Br} M$ Med $\mathcal{F} 1975$;iv:680-2.

${ }^{9}$ Crompton GK, Grant IWB, Bloomfield P. Edinburgh emergency admission service; a report on 10 years' experience. $\mathrm{Br} \mathrm{Med} \mathcal{F} 1979$;ii: 1199-201.

(Accepted 17 April 1984) 